\title{
PDGF autocrine stimulation dedifferentiates cultured astrocytes and induces oligodendrogliomas and oligoastrocytomas from neural progenitors and astrocytes in vivo
}

\author{
Chengkai Dai, ${ }^{1}$ Joseph C. Celestino, ${ }^{4}$ Yoshifumi Okada, ${ }^{2}$ David N. Louis, ${ }^{3}$ Greory N. Fuller, ${ }^{3}$ \\ and Eric C. Holland ${ }^{1,5}$ \\ ${ }^{1}$ Departments of Neurosurgery, and Neurology, and Cell Biology, Memorial Sloan-Kettering Cancer Center, New York, New \\ York 10021, USA; ${ }^{2}$ Department of Pathology and Neurosurgical Service, Massachusetts General Hospital and Harvard \\ Medical School, Boston, Massachusetts 02129, USA; ${ }^{3}$ Department of Pathology, MD Anderson Cancer Center, University of \\ Texas, Houston, Texas 77030, USA
}

We present evidence that some low-grade oligodendrogliomas may be comprised of proliferating glial progenitor cells that are blocked in their ability to differentiate, whereas malignant gliomas have additionally acquired other mutations such as disruption of cell cycle arrest pathways by loss of Ink4a-Arf. We have modeled these effects in cell culture and in mice by generating autocrine stimulation of glia through the platelet-derived growth factor receptor (PDGFR). In cell culture, PDGF signaling induces proliferation of glial precursors and blocks their differentiation into oligodendrocytes and astrocytes. In addition, coexpression of PDGF and PDGF receptors has been demonstrated in human gliomas, implying that autocrine stimulation may be involved in glioma formation. In this study, using somatic cell type-specific gene transfer we investigated the functions of PDGF autocrine signaling in gliomagenesis by transferring the overexpression of PDGF-B into either nestin-expressing neural progenitors or glial fibrillary acidic protein (GFAP)-expressing astrocytes both in cell culture and in vivo. In cultured astrocytes, overexpression of PDGF-B caused significant increase in proliferation rate of both astrocytes and neural progenitors. Furthermore, PDGF gene transfer converted cultured astrocytes into cells with morphologic and gene expression characteristics of glial precursors. In vivo, gene transfer of PDGF to neural progenitors induced the formation of oligodendrogliomas in about $60 \%$ of mice by 12 wk of age; PDGF transfer to astrocytes induced the formation of either oligodendrogliomas or mixed oligoastrocytomas in about $40 \%$ of mice in the same time period. Loss of Ink4a-Arf, a mutation frequently found in high-grade human gliomas, resulted in shortened latency and enhanced malignancy of gliomas. The highest percentage of PDGF-induced malignant gliomas arose from of Ink4a-Arf null progenitor cells. These data suggest that chronic autocrine PDGF signaling can promote a proliferating population of glial precursors and is potentially sufficient to induce gliomagenesis. Loss of Ink4a-Arf is not required for PDGF-induced glioma formation but promotes tumor progression toward a more malignant phenotype.

[Key Words: PDGF; oligodendroglioma; INK4a-ARF; glial differentiation]

Received April 12, 2001; revised version accepted June 1, 2001.

Neuroglial tumors (gliomas), including astrocytomas, oligodendrogliomas, oligoastrocytomas, and glioblastoma, comprise over half of all primary brain tumors. Gliomas are classified into four clinical grades, and the most malignant is referred to as glioblastoma (GBM). A

\footnotetext{
${ }^{4}$ Present address: Breast Center, Baylor College of Medicine, Houston Texas 77030, USA.

${ }^{5}$ Corresponding author.

E-MAIL hollande@mskcc.org; FAX (646) 422-2062.

Article and publication are at http://www.genesdev.org/cgi/doi/10.1101/ gad.903001.
}

number of common mutations have been identified in human gliomas that disrupt the cell cycle arrest pathways leading to p53 and pRb (Louis and Cavenee 1997), the most common of these mutations in high-grade gliomas is the loss of Ink4a-Arf (Ichimura et al. 1996). In addition, gliomas frequently have other mutations and gene expression alterations that lead to constitutive activation of receptor tyrosine kinase signaling pathways, such as epidermal growth factor receptor (EGFR; Wong et al. 1987, 1992), platelet-derived growth factor receptor (PDGFR; Nister et al. 1988; Hermanson et al. 1992, 
1996), fibroblast growth factor receptor (FGFR; Yamaguchi et al. 1994), and insulin-like growth factor receptor (IGFR; Sara et al. 1986; Trojan et al. 1992). How alterations in these two processes function in human gliomagenesis remains unclear. However, animal modeling of these alterations in mice is beginning to identify causal relationships between these genetic alterations and the formation of gliomas (Holland 2001).

The PDGF receptor has two isoforms $(\alpha$ and $\beta)$ and belongs to the receptor tyrosine kinase family (ClaessonWelsh et al. 1989). Upon binding PDGF, these receptors activate a number of downstream signal transduction pathways, including PI3 kinase/AKT, RAS/MAP kinases, and PLC/PKC pathways (de Vries-Smits et al. 1992; Franke et al. 1995; Moriya et al. 1996). Accumulated evidence has suggested that PDGF signaling may play an important role in both normal development and tumorigenesis of the central nervous system (CNS). In cell culture, PDGF functions to block differentiation and promote proliferation of the $\mathrm{O} 2 \mathrm{~A}$ glial progenitor that gives rise to either oligodendrocytes or type- 2 astrocytes (Raff et al. 1983; Noble et al. 1988; Richardson et al. 1988). Although it is known that PDGFR, especially the $\alpha$ isoform, is expressed at high levels in glial progenitors, mature astrocytes also express low levels of PDGFR (Hutchkins 1995; Fruttinger et al. 1996). PDGF and PDGF receptors are frequently coexpressed in human glioma cell lines as well as gliomas including oligodendrogliomas (Nister et al. 1988; Di Rocco et al. 1998; Robinson et al. 2001), and amplification of PDGFR $\alpha$ is found in some high-grade oligodendrogliomas (Shoshan et al. 1999; Smith et al. 2000), suggesting the possible existence of an autocrine loop comprising of PDGF and its receptors (Guha et al. 1995). Recently, PDGF-B chain, encoded in a replication competent retroviral vector system, was shown to induce primary brain tumors in mice with multiple histopathological appearances (Uhrbom et al. 1998). These data indicate that abnormal PDGF signaling can contribute to the etiology of brain tumors, but whether additional mutations are required for gliomagenesis in this system is not known. The variable histology seen in the above experiment may be due to the variety of cell types infected by this vector system. Dissecting the correlation between the histology of PDGFinduced tumors and their cell of origin requires cell typespecific gene transfer.

We have achieved cell type-specific gene transfer of PDGF using the replication competent ALV splice acceptor (RCAS)/tv-a system (Holland and Varmus 1998; Holland et al. 1998a,b). This system consists of the avian leukosis virus (ALV)-based RCAS viral vectors and transgenic mice that express the RCAS receptor TVA from cell type-specific promoters. One mouse line (Gtv-a) expresses the TVA receptor from the astrocyte-specific glial fibrillary acidic protein (GFAP) promoter; a second mouse line (Ntv-a) expresses the TVA from the nestin promoter, as nestin is expressed in the CNS progenitor cells. Comparing the effects of gene transfer to Gtv-a and $\mathrm{Ntv}$-a mice enables us to determine the influence of differentiation status on the ability of a cell to respond to a genetic stimulus. For example, the combined gene transfer of active forms of K-RAS and AKT induces GBM formation from Ntv-a mice but not Gtv-a mice (Holland et al. 2000a), implying that neural progenitors are more sensitive to the oncogenic effects of these particular signaling pathways than differentiated astrocytes.

In this study, we used an RCAS vector that encodes PDGF-B chain to infect Gtv-a and Ntv-a cells both in cell culture and in vivo. In culture, infection with this RCAS vector caused a significant increase in the proliferation rate of both GFAP-expressing astrocytes and nestin-expressing neural progenitors. Additionally, the dramatic changes in morphology and in the expression pattern of cellular differentiation markers are reversibly induced by overexpressing PDGF. These data indicate that signaling from this receptor appears to induce a conversion from differentiated astrocytes to glial precursor-like cells. In vivo, gene transfer of PDGF-B alone induced oligodendroglioma and oligoastrocytoma formation from nestinexpressing neural progenitors and GFAP-expressing astrocytes, respectively. Experimental loss of Ink $4 a-A r f$ was not required for PDGF-induced glioma formation; however, this additional mutation did result in shortened tumor latency and enhanced tumor malignancy. The highest percentage of malignant gliomas arose from the combination of neural progenitor origin and loss of Ink4a-Arf.

\section{Results}

\section{Construction of RCAS vectors}

An RCAS vector containing a bicistronic recombinant construct was generated by connecting the PDGF-B/c-sis and eGFP (green fluorescence protein) coding sequences together with an internal ribosome entry site (IRES), which results in expression of both gene products and allows detection of infection of cells. This vector is referred to as RCAS-PBIG (RCAS-PDGF-B-IRES-EGFP). A second RCAS vector was also constructed that contains only the PDGF-B sequence and is referred to as RCAS-PB (RCAS-PDGF-B). The vectors, along with an RCAS vector carrying the gene encoding $\beta$-galactosidase (lacZ) (gift of Yi Li, Memorial Sloan-Kettering Cancer Center, New York, NY) and another RCAS vector carrying polyoma virus middle $\mathrm{T}$ antigen (MTA) (Holland et al. 2000b), were propagated in the chicken fibroblast cell line DF-1.

PDGF-B overexpression promotes proliferation of both GFAP-expressing astrocytes and nestin-expressing CNS progenitors in cell culture

To test the mitogenic functions of PDGF-B in specific cell types, we infected primary brain cell cultures from both Gtv-a (astrocytes) and Ntv-a (glial progenitors) transgenic mice with RCAS-PB, RCAS-PBIG, and RCAS-lac $Z$ vectors respectively. After infection, these cells were passaged in culture for $40 \mathrm{~d}$ and their proliferative capacity was measured by growth curves (Holland et al. 1998b). Infection of either Gtv-a (Fig. 1A) or 
A

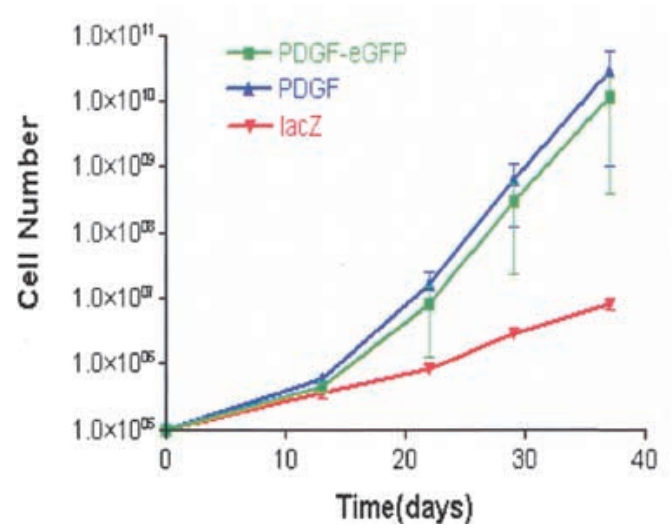

B

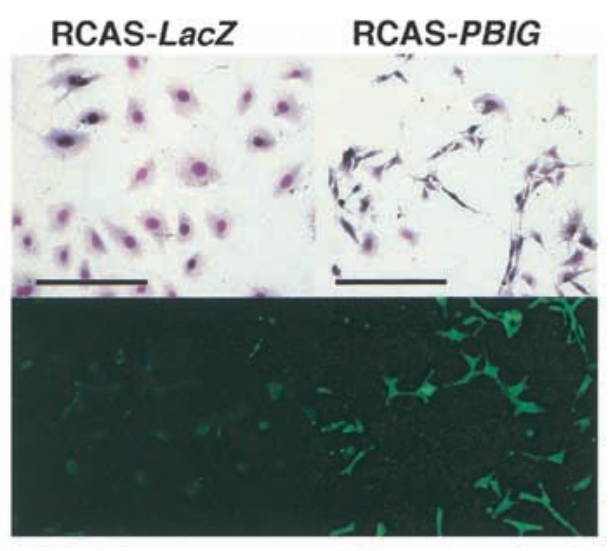

C

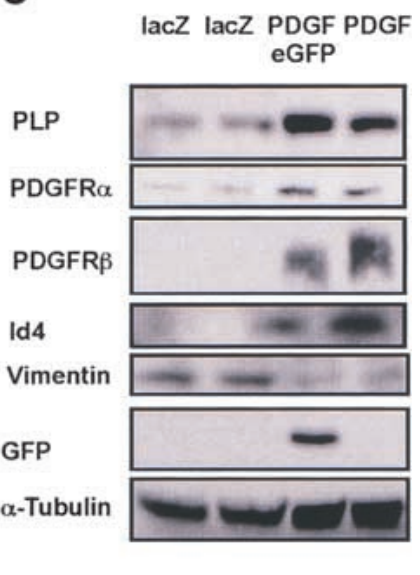

Figure 1. Dedifferentiation of cultured astrocytes to glial progenitors caused by overexpression of PDGF-B chain. $(A)$ The proliferation rate of primary astrocytes (from Gtv-a mouse) was significantly increased by overexpression of PDGF-B. The details of generating growth curve are described in Material and Methods. $(B)$ Giemsa staining shows the morphology of cultured cells infected with RCAS-LacZ and RCAS-PBIG from Gtv-a, Ink $4 a-A r f^{+/+}$mouse. Fluorescence microscopy shows that the cells infected with RCAS$P B I G$ are expressing green fluorescent protein. Both photomicrographs are $100 \times$ magnification; bars, $100 \mu \mathrm{m}$. $(C)$ Western blot analyses show the increased expression of molecular markers for glial precursors in the astrocytes after RCAS-PBIG infection. Two lines of RCAS-lacZ-infected astrocytes were used as control. (PLP) Myelin proteolipid protein; (PDGFR) platelet-derived growth factor receptor; (GFP) green fluorescent protein; (Id4) inhibitor of binding 4, a dominant negative HLH protein. $\alpha$-Tubulin was used as loading control.

Ntv-a cell cultures (data not shown) with PDGF-encoding viruses resulted in a substantial increase in the growth rate of these cells relative to infection with the control LacZ-encoding vector. A similar growth rate was seen for both RCAS-PBIG and RCAS-PB indicating that the expression of GFP did not affect the growth potential of these cells. Cells infected with RCAS-PBIG were visualized by green fluorescence secondary to the expression of eGFP (Fig. 1B).

\section{PDGF/PDGFR autocrine loop stimulation}

dedifferentiates GFAP-expressing astrocytes to glial precursor-like cells in culture

In addition to the enhanced proliferative capacity induced by PDGF signaling, PDGF also induced morphological and gene expression characteristics of undifferentiated cells. These changes were most striking in the astrocytes from Gtv-a mice. After $40 \mathrm{~d}$ in culture, the control RCAS-lacZ-infected Gtv-a cells showed a large, flat morphology expected for cultured astrocytes. In contrast, both RCAS-PB and RCAS-PBIG infected Gtv-a cells showed a small, elongated, bipolar or simple multipolar morphology, characteristics of glial progenitor cells (Fig. 1B).

Western blot and immunocytochemical analyses showed gene expression patterns similar to that of glial precursors (Fig. 1C). Expression of myelin proteolipid protein (PLP) (Asakura et al. 1998; Spassky et al. 1998), PDGFR $\alpha$ (Hart et al. 1989; Hall et al. 1996) and $\beta$, A2B5 (Williams et al. 1985; Dubois-Dalcq 1987; data not shown), all known as markers for glial progenitors, were up-regulated in cells infected with PDGF-encoding vectors. Moreover, these cells also showed elevated expression of Id4, an HLH gene whose expression is shown to correlate inversely with differentiation status of oligodendrocyte precursors (Andres-Barquin et al. 1999; Kondo and Raff 2000; Nogueira et al. 2000). By contrast, these cells did not express O4 antigen, which is expressed in premature and mature oligodendrocytes (Sommer and Schachner 1981), implying that they are not differentiating to oligodendrocytes. Of note, NG2, which is expressed in bipotential O2A progenitors (Stallcup and Beasley 1987), was not expressed in these cells, nor was the expression of neuronal markers such as neurofilament (NF) or synaptophysin (data not shown). Therefore, the expression pattern of cellular markers, along with the morphology and the proliferation capacity, suggest an early glial precursor stage for these cells, similar but not identical to the well-known O-2A progenitors (Raff et al. 1983). The potential for autocrine loop stimulation of PDGF and PDGFR is demonstrated by the elevated expression of both PDGFR $\alpha$ and $\beta$ compared with the RCAS-lacZ-infected cells.

\section{Blocking PDGF autocrine signaling reverses the PDGF-induced phenotype in vitro}

The PDGF-induced alterations described above could either be direct effects of elevated PDGF signaling or a result of selection for growth advantage in culture. To address this issue, we treated long-term cultured PDGFtransformed astrocytes (from Gtv-a mice) with a tyrosine kinase inhibitor (PTK787/ZK222584) (Wood et al. 2000) that blocks the activation of PDGF receptors. At $1 \mu \mathrm{M}$ 
Dai et al.

drug concentration, the proliferation rate of the PDGFexpressing cells was dramatically inhibited (Fig. 2A,B) and the progenitor-like morphology reverted back to a large, flat, astrocyte-like morphology (Fig. 2C). Western blot analyses of RCAS-PBIG-infected astrocytes showed that the expression levels of PLP and Id4 were downregulated by treatment with PTK787 implying a direct effect of PDGF signaling in control of these genes. In contrast, the elevated PDGFR $\alpha$ and PDGFR $\beta$ levels seen in the PDGF overexpressing astrocytes were not reduced by PTK787, suggesting that the elevated expression of PDGFRs may be due to selection during extended culture for cells with high level of PDGFR expression that can maximally respond to overexpression of PDGF. The expression level of eGFP pre- and post-drug treatment was similar, indicating that the effects of PTK787 were not due to decreased expression of virally encoded PDGF-B (Fig. 2D). We demonstrated that this effect of PTK787 was not a general property of this drug by its effect on astrocytes infected with an RCAS vector carrying the coding sequence for polyoma middle $\mathrm{T}$ antigen (RCAS-MTA). MTA expression can activate similar signal transduction pathways as PDGF and infection with RCAS-MTA causes increased proliferation rate of astrocytes in cell culture and induces oligoastrocytomas from astrocytes in vivo (Holland et al. 2000b). At the same concentration of PTK787 that reversed the phenotype of RCAS-PBIG-infected cells, there was no effect on the proliferation capacity or morphology of RCAS-MTAinfected cells, implying specificity of the PTK787 effect for signaling through PDGFR in these glial cells.

\section{Gene transfer of PDGF-B into nestin-expressing neural progenitors induces oligodendroglioma formation in mice}

To investigate the effect of PDGF autocrine loop stimulation on these same cell types in vivo, we infected Ntv-a and Gtv-a transgenic mice with RCAS-PBIG by a single intracranial injection of about $10^{4} \mathrm{DF}-1$ cells producing this vector. All the mice were sacrificed at the end of week 12, or earlier if they showed signs or symptoms of intracranial disease such as macrocephaly or lethargy. The brains were fixed and sections were analyzed by standard hemotoxylin and eosin (H\&E) staining. Previous experiments have demonstrated that gene transfer of the marker gene alkaline phosphatase, activated Ras, or activated Akt alone to either of these mouse lines by this procedure does not induce tumors or histologic abnormalities (Holland and Varmus 1998; Holland et al. 2000a).

Initially, we directly infected a total of 34 newborn
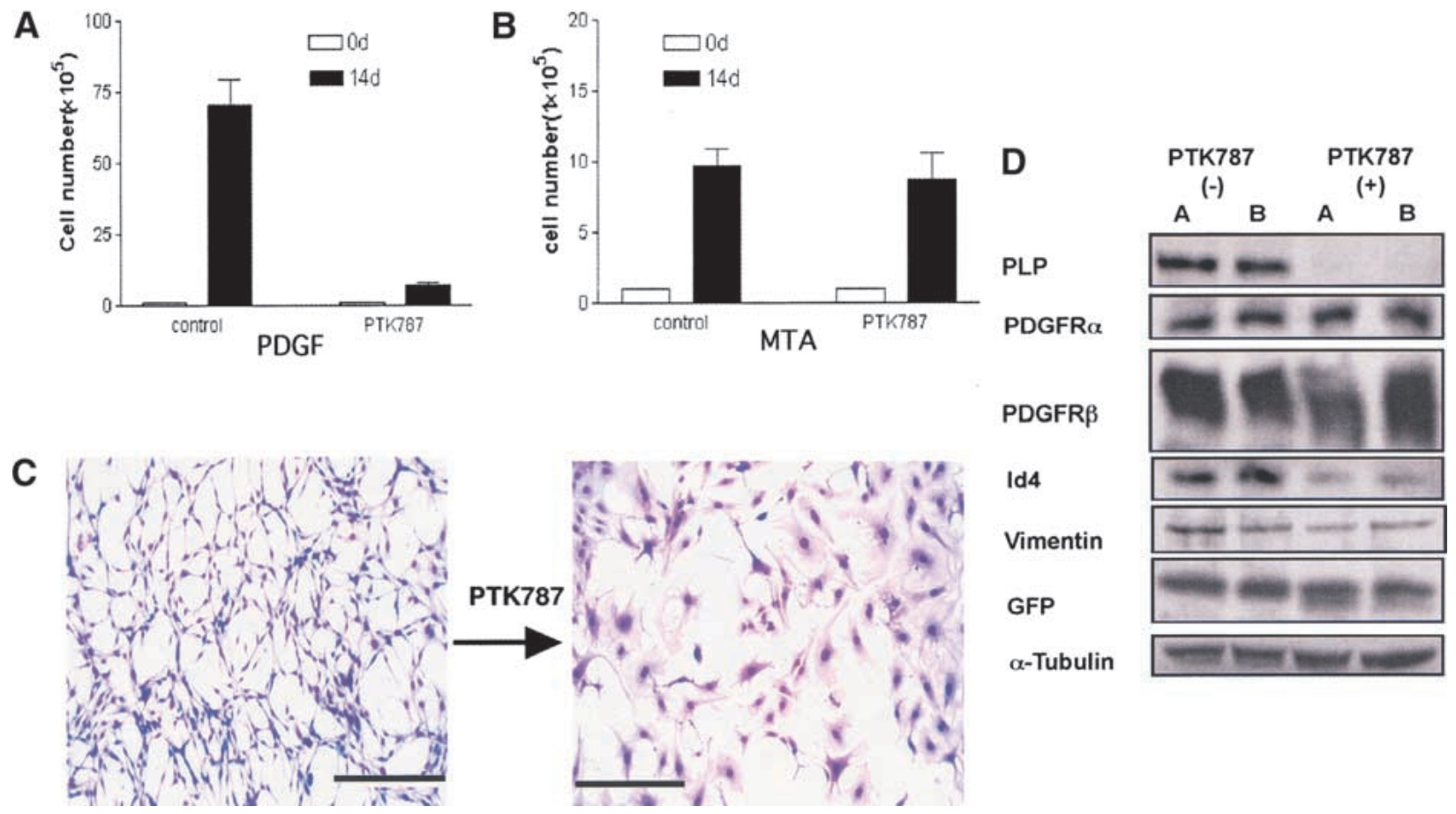

Figure 2. Reversion of PDGF-induced phenotypic effects by blocking PDGF receptor kinase. Astrocytes $\left(1 \times 10^{5}\right)$ were plated and grown in culture either with or without $1 \mu \mathrm{M}$ PTK787 that inhibits the PDGF receptor kinase. The cells were counted after $14 \mathrm{~d}$. $(A)$ The proliferation of RCAS-PBIG-infected cultured astrocytes was inhibited by $1 \mu$ M PTK787 treatment. In contrast, the proliferation of RCAS-MTA-infected astrocytes was not inhibited by PTK787 (B). (MTA) Polyoma virus middle T antigen. (C) Giemsa staining shows the morphology of RCAS-PBIG-infected astrocytes with and without $1 \mu \mathrm{M}$ PTK787 for $14 \mathrm{~d}$. 100× magnification; bars, $100 \mu \mathrm{m}$. (D) Western blot analyses show the changes in expression pattern of molecular markers after blocking autocrine PDGF stimulation. (PLP) Myelin proteolipid protein; (PDGFR) platelet-derived growth factor receptor; (GFP) green fluorescent protein; (Id4) inhibitor of binding 4, a dominant negative HLH protein. $\alpha$-Tubulin was used as loading control. 
Ntv-a transgenic mice. Over $60 \%$ of this population of mice harbored gliomas. Histologically, these tumors were diffusely infiltrating neoplasms composed of small tumor cells with monotonous, regular round nuclei surrounded by cleared cytoplasm ("perinuclear halos") (Fig. 3B). These morphologic features are identical to those seen in human oligodendrogliomas. The tumors did not express neuronal differentiation markers, such as NeuN and synaptophysin, as demonstrated by immunohistochemistry (data not shown). Further, also similar to human oligodendrogliomas, except for scattered entrapped reactive astrocytes the majority of tumor cells were immunonegative for GFAP, suggesting the absence of astrocytic differentiation (Fig. 3C). In addition to the morphologic and immunohistochemical similarity of the individual tumor cells to human oligodendrogliomas, the infiltrative behavior and interactions with normal host cellular constituents also closely resembled that seen in human gliomas. The murine gliomas displayed all of the classical morphologic formations seen in infiltrating human oligodendrogliomas referred to as secondary structures of Scherer (1938); including intrafascicular queuing in white matter tracts of the corpus callosum and subpial infiltration, perivascular satellitosis, and perineuronal satellitosis in areas of cortical invasion (Fig. 4). The expression of exogenous PDGF in these tumors was verified by positive immunostaining for eGFP expression (data not shown).

In the experiment reported here, both low- and high- grade tumors arose from PDGF gene transfer in vivo. The high-grade oligodendrogliomas, called anaplastic oligodendrogliomas in the current World Health Organization Classification of Tumours (WHO 2000), were characterized by dense cellularity without intervening neuropil, easily identifiable mitotic figures, cellular and nuclear pleomorphism and microvascular proliferation (Fig. 3DF). These anaplastic oligodendrogliomas frequently were additionally characterized by the presence of foci of tumor necrosis with surrounding tumor cell pseudopalisading (Fig. 3F). The majority of the PDGF-induced gliomas, arising in either Gtv-a or Ntv-a mice having a wildtype genetic background, were low-grade tumors that lacked the features just described for high-grade oligodendrogliomas.

\section{Loss of Ink4a-Arf enhances tumor initiation and tumor progression in Ntv-a transgenic mice}

The above data suggest that autocrine stimulation of PDGF signaling, in the absence of other experimentally induced genetic alterations, could be sufficient to induce low-grade gliomas from neural progenitors. Human highgrade gliomas have additional mutations that result in disruption of cell cycle arrest pathways such as loss of Ink4a-Arf (Cairncross et al. 1998) To elucidate the roles of disruption of G1 cell cycle arrest pathway in PDGFinduced gliomagenesis, we compared the incidence and characteristics of gliomas occurring in both Ink $4 a-\mathrm{Arf}^{+/+}$
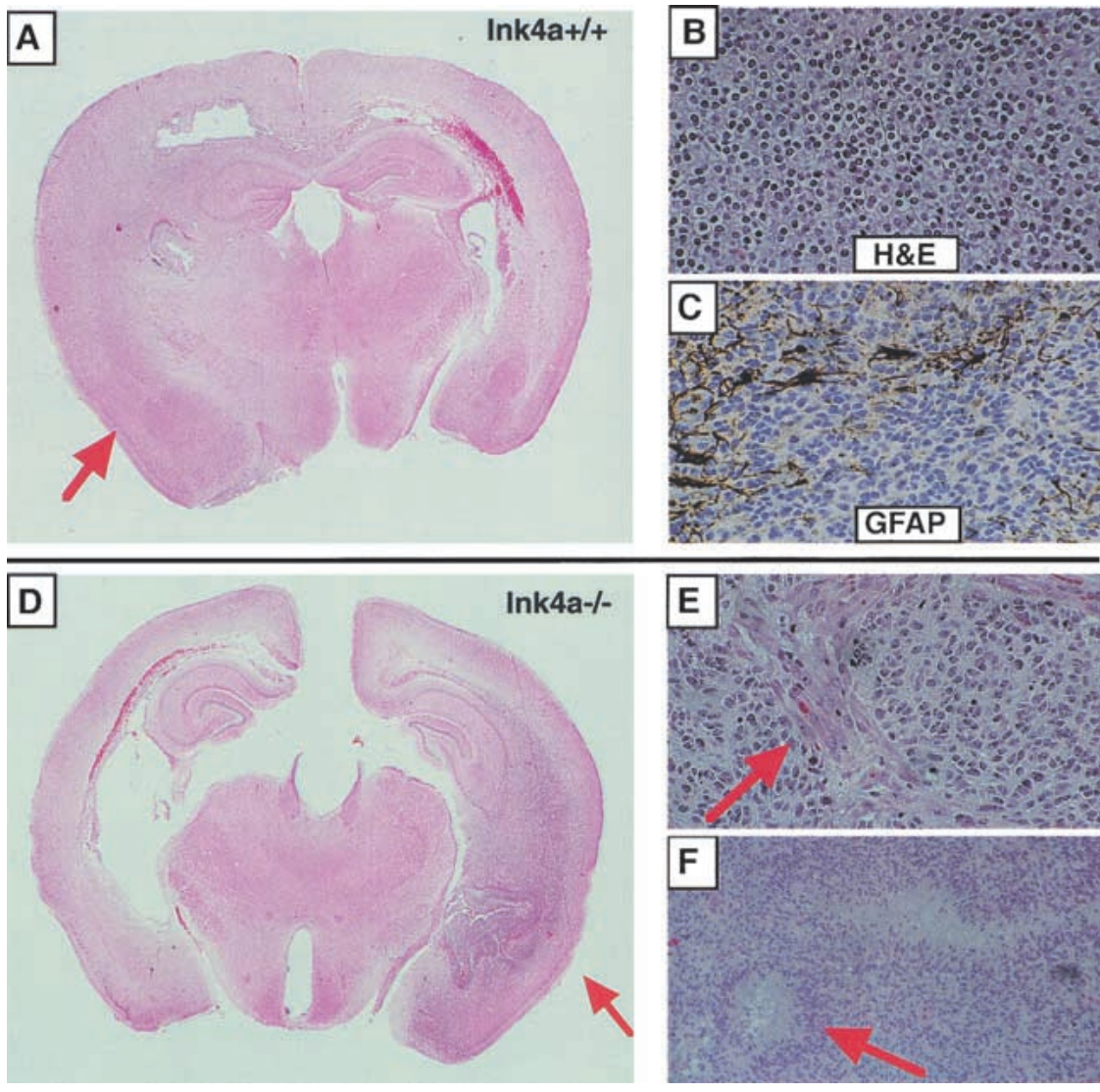

Figure 3. Histologic analysis of oligodendrogliomas induced from neural progenitors. PDGF-induced gliomas in Ntv-a mice with either Ink4a-Arf ${ }^{+/+}(A-C)$ or Ink4a$A r f^{-/-}(D-F)$ genetic backgrounds. $(A)$ Low magnification of H\&E-stained section illustrates the diffuse infiltrating low-grade tumor (indicated by the arrow). (B) H\&Estained section shows small, homogenous tumor cells with perinuclear "halo" appearance. $(C)$ GFAP immunostaining shows negative oligodendroglioma cells and a few positive, trapped reactive astrocytes. (D) Low magnification of H\&Estained section illustrates a high-grade oligodendroglioma. The arrow indicates the necroses. (E) H\&E-stained section shows microvascular proliferation (indicated by the arrow), a criterion for diagnosing highgrade gliomas. $(F) \mathrm{H} \&$ E-stained section shows the palisading necrosis (indicated by the arrow), a criterion for diagnosing highgrade gliomas. 
Dai et al.

Figure 4. Invasion of normal brain structures by mouse glioma cells. Similar to what is seen in human gliomas, these mouse tumors migrate along the white matter tracts $(A)$, and surround neurons $(B)$, and collect adjacent to the pial surface of the brain and blood vessels $(C, D)$. Arrows indicate the listed structures.
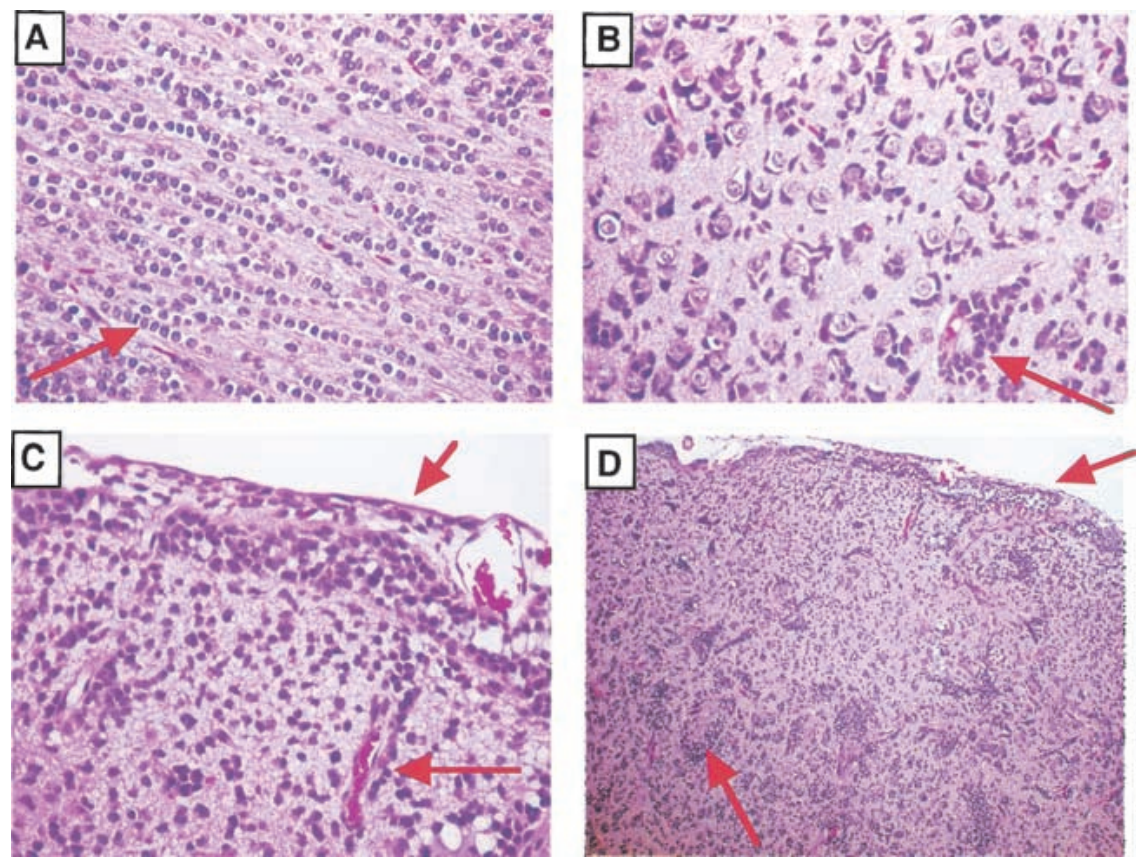

and $\operatorname{Ink} 4 a-A r f^{-1-}$ mice. At 12 wk of age, $61 \%$ of $\operatorname{Ink} 4 a-$ $\mathrm{Arf}^{+/+}$and $57 \%$ of Ink4a-Arf ${ }^{-/-}$mice developed gliomas respectively (Fig. 5A). All of these tumors were oligodendrogliomas according to the above histopathological criteria and as described in the WHO 2000 classification. Although the overall glioma incidence was similar between these two groups, over half of the gliomas forming in Ink $4 a-A r f^{+/+}$mice were low-grade and asymptomatic at the 12 -wk time point whereas only about $10 \%$ of tumors arising from Ink $4 a-a r f^{-/-}$mice were low grade. By contrast, using the same criteria these Ink $4 a-A r f^{-/-}$tumors not only were more likely to be malignant but were also more likely to be symptomatic, resulting in earlier sacrifice and analysis (Fig. 5A,B). Therefore, experimental disruption of the Ink4a-Arf locus appears not essential for the induction of these gliomas from nestin-expressing neural progenitors; however, it does either facilitate the progression of gliomas toward a more malignant phenotype, or it selects for a more aggressive tumor cell that outgrows the population in vivo.
A

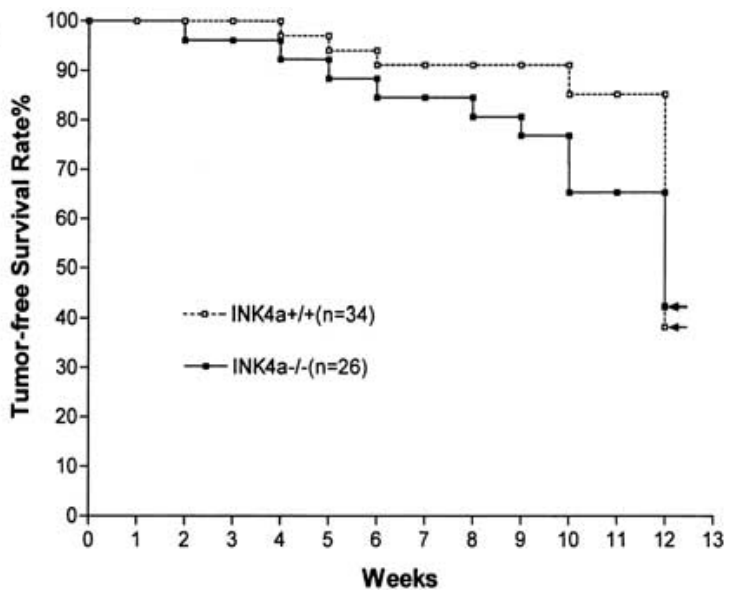

B

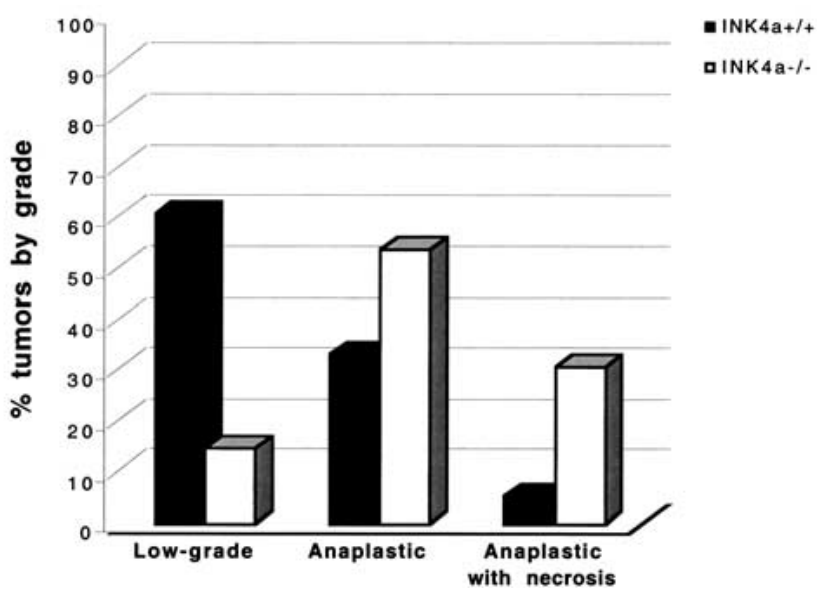

Figure 5. Role of Ink4a-Arf loss in PDGF-induced gliomagenesis from neural progenitors. $(A)$ Tumor-free survival curve indicating percent of mice developing symptomatic tumors over time. All mice were sacrificed at $12 \mathrm{wk}$; clinically occult tumors are indicated by the vertical line at $12 \mathrm{wk}$. The total number of mice without detectable tumors at $12 \mathrm{wk}$ was $~ 40 \%$ in both animal groups as indicated by the arrows. (B) Ink4a-Arf loss significantly enhanced tumor malignancy. The grading criteria are described in the text. (O) Oligodendroglioma (WHO classification); (AO) anaplastic oligodendroglioma (WHO classification). AO tumors having the histologic feature of pseudopalisading necrosis are listed as "anaplastic with necrosis." 
Gene transfer of PDGF-B into GFAP-expressing astrocytes induces either oligodendrogliomas or mixed oligoastrocytomas in mice

The experiments described thus far were performed in $\mathrm{Ntv}$-a mice, that is, gene transfer to nestin-expressing neural progenitors. To test the influence of cell of origin on PDGF-induced gliomagenesis, we infected Gtv-a transgenic mice (astrocytes) with RCAS-PBIG. The total incidence of glioma formation was somewhat lower $(\sim 40 \%)$, and the tumors were either oligodendrogliomas or gliomas of mixed histology containing both oligodendroglioma and astrocytoma components /oligoastrocytoma). Figure 6A shows a representative example of an oligoastrocytoma in which distinct oligodendroglioma and astrocytoma components are present. The oligodendroglioma component exhibits morphologic features identical to those seen in human oligodendrogliomas, including monotonous, uniform round nuclei and scantto-nondetectable cytoplasm. By contrast, in the astrocytoma component the constituent tumor cells are more pleomorphic and atypical, with irregular nuclei and prominent eosinophilic cytoplasm that is strongly immunoreactive for GFAP (Fig. 6B,C). In addition, multinucleated giant cells are intimately associated with the astrocytoma component (data not shown), as is sometimes seen in human astrocytomas. These gliomas arising in Gtv-a mice also occurred in low-grade and malignant forms. However, over $70 \%$ of these tumors were low grade in mice with a wild-type Ink $4 a-A r f$ genetic background.

In Gtv-a mice, loss of Ink4a-Arf increases tumor incidence and tumor malignancy

To test the effects of Ink4a-Arf loss on the formation of the mixed gliomas arising from astrocytes in Gtv-a mice, we compared PDGF-induced glioma formation in Gtv-a, $\operatorname{Ink} 4 a-A r f^{+/+}$and Gtv-a, Ink4a-Arf ${ }^{-/-}$mice. Similar to the Ntv-a mice, gliomas arising from Gtv-a mice with Ink4a-Arf deficiency were of higher grade and shorter latency than those in mice with an Ink4a-Arf wild-type background (Fig. 7A). In contrast to Ntv-a mice, in which a higher percentage of animals developed gliomas and no increase in tumor incidence was seen with $\operatorname{Ink} 4 a-A r f$ loss, loss of Ink $4 a-A r f$ in Gtv-a mice resulted in a nearly twofold increase in the incidence of PDGF-induced gliomas at $12 \mathrm{wk}$ of age (Fig. 7A). The most malignant gliomas with the shortest latency were seen with the combination of both neural progenitor cell of origin and loss of Ink4a-Arf (Fig. 7B).

\section{Deletions of $1 p, 19 q$, and $10 q$ are not present in PDGF-induced gliomas}

It is not clear whether PDGF signaling is sufficient for the induction of oligodendrogliomas or whether additional chromosomal abnormalities during tumor initiation or progression are required to cooperate with PDGF signaling in gliomagenesis. We investigated this question by analyzing these tumors for allelic loss of the mouse chromosomes syntenic to regions that are frequently lost in human gliomas. Approximately half of human oligodendrogliomas demonstrate deletions of chromosomes $1 \mathrm{p}$ and $19 \mathrm{q}$, and malignant gliomas often show loss of chromosome 10q (Ransom et al. 1992; Reifenberger et al. 1994; von Deimling et al. 1992; Bello et al. 1995; Maier et al. 1997). Such regions would be likely candidates for additional mutations that might be required for PDGF-induced glioma formation. We addressed this issue by using fluorescence in situ hybridization (FISH) for murine loci that are syntenic to the candidate tumor suppressor regions on human chromosomal arms 1p, 10q, and 19q. Murine chromosomal arms (murine 3, 84.9 cM and murine 4, 46.6 and $81.5 \mathrm{cM}$, for human 1p; murine 7, 4-5.5 and $23.0 \mathrm{cM}$ for human $19 \mathrm{q}$; and murine 19, $26.0 \mathrm{cM}$ for human 10q), and corresponding centromeres were studied in 21 PDGF-induced glio-
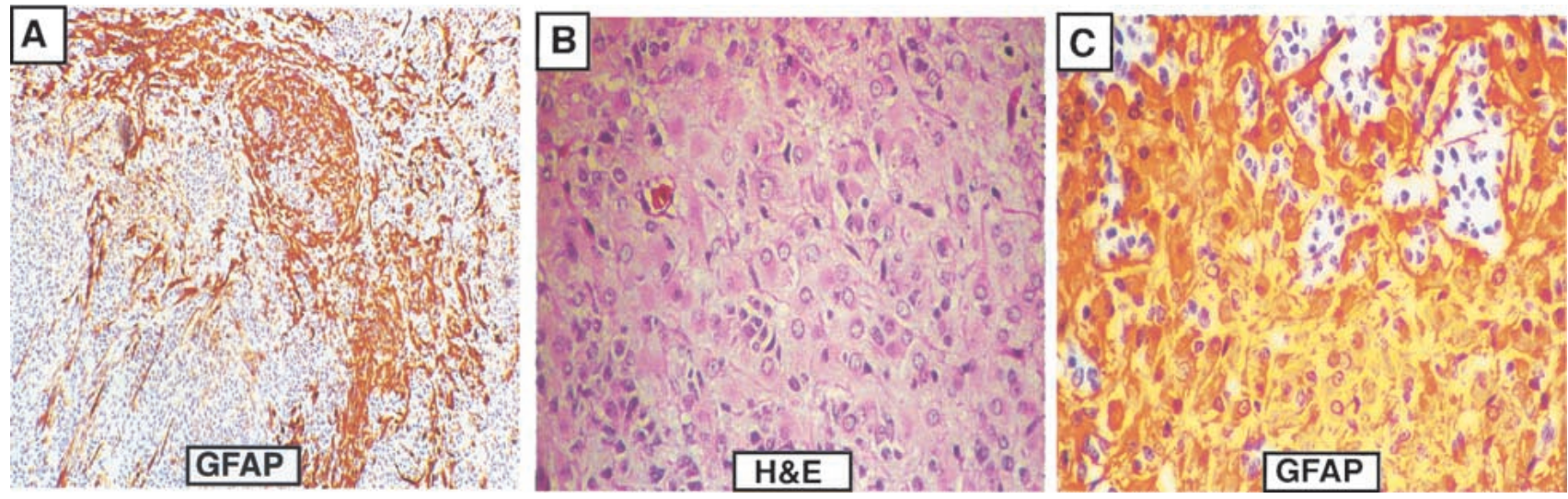

Figure 6. Histology of mixed gliomas induced from GFAP-expressing astrocytes. $(A)$ Low magnification of GFAP-immunostained section illustrates the coexistence of both positive astrocytoma cells and negative oligodendroglioma cells. $(B) \mathrm{H} \& \mathrm{E}$-stained section shows astrocytic tumor cells with irregular nuclei and eosinophilic cytoplasm. $(C)$ GFAP immunostaining illustrates the strongly positive astrocytoma cells; the staining pattern distinguishes them from reactive astrocytes. 

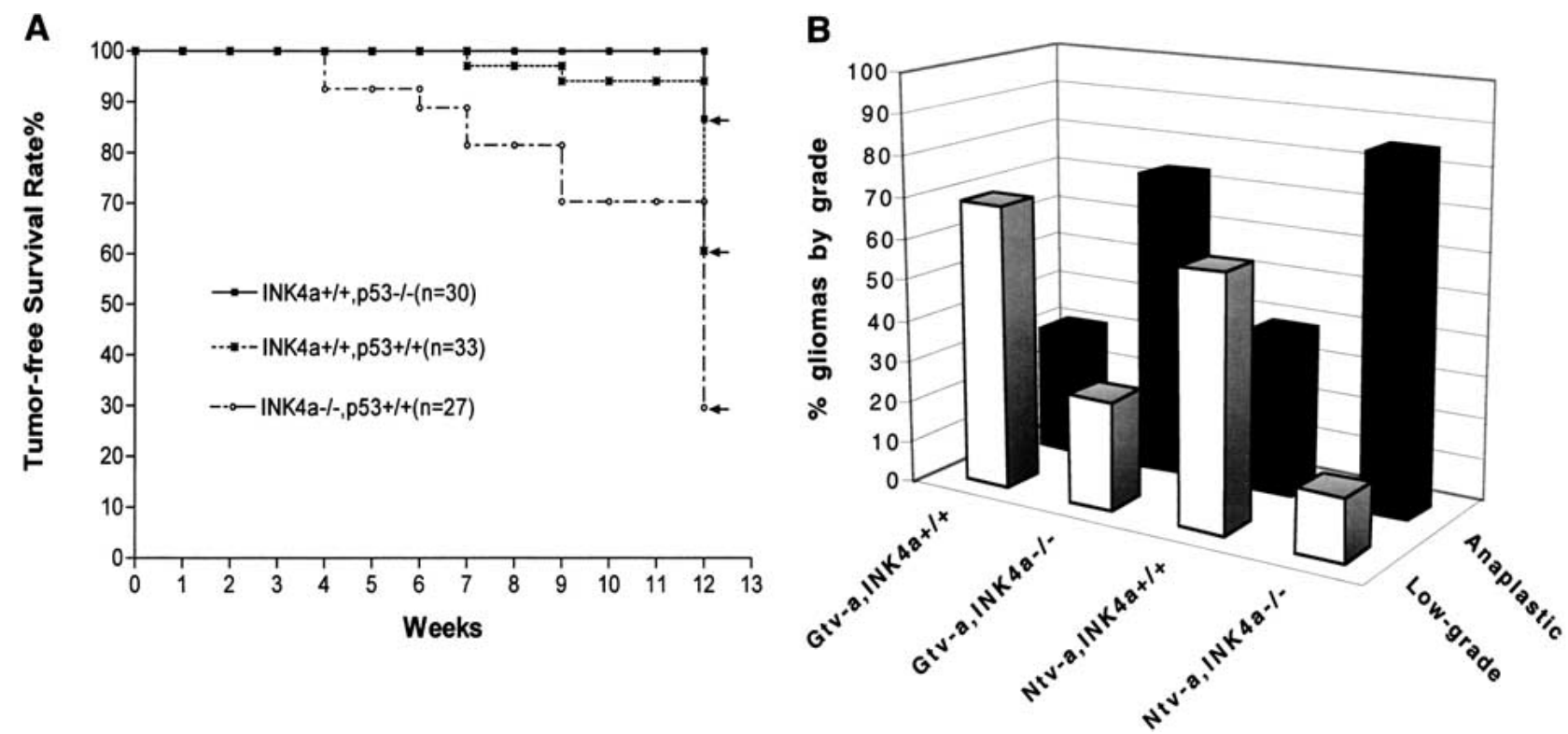

Figure 7. Role of Ink4a-Arf loss, p53 loss in PDGF-induced gliomagenesis from Gtv-a mice. (A) Ink4a-Arf loss, but not p53 loss, resulted in a shortened tumor latency and an increased total tumor incidence $(70 \%$ vs. $39 \%)$; $(B)$ Ink $4 a-A r f$ loss also significantly enhanced the malignancy of gliomas induced from Gtv-a mice. In summary, the most malignant gliomas arose from the combination of both neural progenitor cell of origin and loss of Ink4a-Arf. (O) Oligodendroglioma (WHO classification); (AO) anaplastic oligodendroglioma (WHO classification). Final tumor incidence for each genetic background is indicated by the arrows.

mas of various grades. For each case at each locus, the chromosomal counts ranged from 1.71 and 2.08 , satisfying the criteria for two chromosomal copies (Fig. 8). Thus, in no case was there evidence for loss of any of these regions. Therefore, those common mutations implicated in human oligodendrogliomas appear not to be required for PDGF-induced glioma formation. These data may imply that PDGF signaling achieves the same biologic effect as $1 \mathrm{p}$ and $19 \mathrm{q}$ loss and that there is no selective pressure for generating these mutations, or that that this model may simulate those human oligodendrogliomas without such mutations.

\section{Experimental loss of p53 does not promote PDGF-induced gliomagenesis}

The above data indicate that some of the common genetic alterations found in human gliomas do not occur in our PDGF-induced model for gliomas, potentially imply- ing that other mutations are not required for PDGFinduced gliomagenesis. To further investigate the possibility that additional mutations might enhance the formation of PDGF-induced gliomas, we crossed the Gtv-a mice to a $p 53^{-/-}$background. Loss of p53 has been shown to induce chromosomal instability in some tumor model systems and cultured astrocytes (Donehower et al. 1995; Yahanda et al. 1995; Bertrand et al. 1997). Intriguingly, mice with a $p 53^{-/-}$genetic background showed neither shortened tumor latency nor increased incidence of PDGF-induced gliomas relative to wild type mice (Fig. 7A). In fact, there appeared to be a somewhat lower tumor incidence in these $\mathrm{p} 53^{-/-}$mice. This result is consistent with the finding that TP53 mutations rarely occur in human oligodendrogliomas (Ohgaki et al. 1993; Reifenberger et al. 1994; Bigner et al. 1999). In contrast, p53 loss cooperates with combined activation of Ras and Akt pathways in Gtv-a mice to induce glioblastomas (E.C. Holland et al., unpubl.), which is also consistent

Figure 8. Fluorescence in situ hybridization analysis of PDGF-induced gliomas. (A) Two copies of murine chromosome 4 syntenic to human chromosome 1p. Green and red signals indicate the locus of murine chromosome 4, centromere and 81.5 $\mathrm{cM}$, respectively. $(B)$ Two copies of murine chromosome 7 syntenic to human chromosome 19q. Green signals are for the centromere of murine chromosome 7 , and red for chromosome 7, $23 \mathrm{cM}$.
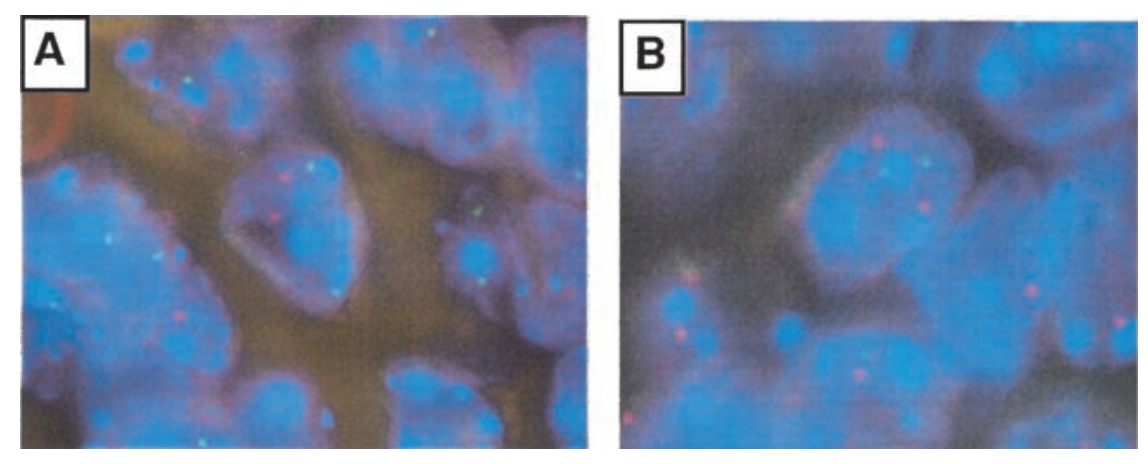
with the high frequency of TP53 mutations in human astrocytic tumors (Louis et al. 1993; Wu et al. 1993; Weber et al. 1996). Therefore, although it remains formally possible that additional mutations are required for PDGF-induced glioma formation in mice, if such mutations exist they are not the common ones found in human oligodendrogliomas nor is their occurrence enhanced by loss of p53.

\section{Discussion}

Previous studies indicate that PDGF signaling functions during glial cell development by maintaining glial precursors in an undifferentiated and proliferating state. By forcing the overexpression of PDGF we have induced an autocrine signaling loop in cells that also express the PDGF receptor. In our experiments, the alterations in proliferation rate, cell morphology, and gene expression pattern in cultured astrocytes infected with RCAS-PBIG indicate that PDGF autocrine stimulation can dedifferentiate GFAP-expressing astrocytes to glial progenitorlike cells. This process can be reversed by blocking the PDGF receptor kinase, indicating that these PDGFdriven cells continue to depend on signaling through the PDGF receptor in culture, and have not genetically evolved to be independent of these signaling pathways.

The in vivo equivalent of this dedifferentiation effect of PDGF autocrine stimulation, and maintenance of glial progenitors in a proliferative capacity, appears to be the formation of low-grade gliomas. Depending on the cell of origin, these tumors are either predominantly oligodendrogliomas from glial progenitors or oligoastrocytomas from astrocytes. Similar to human gliomas, the lowgrade mouse gliomas do not have Ink $4 a-A r f$ loss. Additional Ink4a-Arf loss in the mouse model results in increased malignancy but only a modest increase in tumor incidence. All of these data are consistent with the hypothesis that low-grade gliomas may represent collections of glial progenitors that are trapped in an undifferentiated and proliferating state. There could well be numerous mechanisms that lead to glial progenitors being unable to differentiate in vivo. PDGF autocrine stimulation models this phenomenon in mice and may be responsible for a subset of human oligodendrogliomas. The conversion of these tumors to high-grade neoplasms could be due to acquisition of additional mutations, such as Ink4a-Arf loss, and result in an outgrowth of tumors with increased malignancy. This hypothesis implies that low-grade gliomas may respond well to drugs that promote differentiation such as histone deacetylase inhibitors and retinoic acid derivatives, and in some cases potentially PDGFR kinase inhibitors. High-grade gliomas that have additional mutations may be more refractory to this strategy alone.

The evidence presented in this paper indicates that PDGF signaling alone may be sufficient to induce glioma formation. The reversion of PDGF-induced phenotypes in vitro by blocking PDGF signaling strongly implies that PDGF signaling is necessary and sufficient to main- tain the transformed phenotypes of these cells in culture. At least in culture, these cells evolve to depend on the initiating event. Although it is possible in vivo that additional mutations occur that give rise to gliomas, the limited number of cells infected in each mouse and the high efficiency of glioma formation make the requirement for other mutations unlikely. The FISH data supports this idea by demonstrating that some of the common mutations found in human oligodendrogliomas, loss of $1 \mathrm{p}, 19 \mathrm{q}$, and $10 \mathrm{q}$, were not found in PDGF-induced oligodendrogliomas. Furthermore, p53 deficiency did not enhance the formation of these tumors. These data imply, but do not prove, that other mutations may not be required for the induction of low-grade gliomas induced by autocrine PDGF stimulation. It is possible that additional mutations do occur in the tumors in vivo; nevertheless, this would not necessarily indicate that such mutations are required for tumor initiation rather than required for, or a product of, tumor progression.

Other signaling molecules or modeling strategies may generate gliomas with an oligodendroglioma histology similar to the one presented in this paper. It would not be surprising that other such models may cooperate differently with specific tumor suppressor loss, or result in chromosomal abnormalities not found in these PDGFinduced gliomas in our model. Given the known varied clinical responses to treatment and molecular genetic analyses of human gliomas, it would appear that there are multiple molecular subgroups within each of the glioma grades and types, including oligodendrogliomas (Cairncross et al. 1998; Ino et al. 2001). It is possible that different modeling approaches may effectively mimic different subgroups of oligodendrogliomas that are histologically similar, but are biologically and clinically distinct.

\section{Materials and methods}

Construction of RCAS vectors

pSM-1, human PDGF-B/c-sis cDNA clone, was digested with BamHI and SspI restriction enzymes. The 927-bp fragment including the entire coding sequence of PDGF-B chain was subcloned into RCAS vector with and without the IRES-EGFP sequence. These vectors are referred to as RCAS- $P B$ and RCAS$P B I G$, respectively.

\section{Transfection of DF-1 cells}

DF-1 cells were grown in DMEM medium complemented with $10 \%$ fetal calf serum. RCAS-PB, RCAS-PBIG, RCAS-MTA, and RCAS-lacZ plasmid DNAs were transfected into chicken DF-1 cells by using calcium phosphate precipitation methods and the vectors were allowed to replicate within the producer cell population.

\section{TV-a transgenic mice}

The Gtv-a mouse line that expresses tv-a from the GFAP promoter and the Ntv-a mouse line that expresses tv-a from the nestin promoter have been published (Holland and Varmus 1998; Holland et al. 1998a). The mice are a mixed genetic back- 
ground including contribution from C57B16, 129, Balb/C, and $\mathrm{FVB} / \mathrm{N}$.

\section{Primary brain cell cultures}

Newborn tv-a transgenic mice were sacrificed and the whole brains were mechanically dissociated into small pieces in sterile PBS, $\mathrm{Ca}^{2+}, \mathrm{Mg}^{2+}$ free ( $\mathrm{pH} 7.4$ ), followed by digestion with $1 \mathrm{~mL}$ of $0.25 \%$ Trypsin-1 mM EDTA in HBSS (GIBCO BRL) in sterile tubes and incubation in $37^{\circ} \mathrm{C}$ water bath for 15 min with gentle shaking. After incubation, fresh medium was added to terminate Trypsin digestion and large debris was settled. The single cells were pelleted, resuspended in DMEM with $10 \%$ fetal calf serum (GIBCO BRL), and plated.

\section{Infection of primary brain cell culture and growth} rate analysis

The supernatants containing various RCAS virons from DF-1 cell cultures transfected with various RCAS vectors were collected using sterile syringes and filtered through $0.22 \mu \mathrm{m}$ filters, followed by transferring into $70 \%-80 \%$ confluent primary brain cell cultures that had been plated and grown in DMEM with $10 \%$ fetal calf serum. Infections were repeated 3 times with 12-h intervals. After infection, the proliferation rates were measured. Briefly, the cells were harvested by trypsin digestion and counted using a hemocytometer. Total $1 \times 10^{5}$ cells were replated and grown in DMEM with $10 \%$ fetal calf serum until the cells reached confluence; the same procedure was repeated over time. Finally, the total accumulated cell numbers were calculated and plotted as growth curves.

\section{Fluorescence microscopy}

DF-1 cells transfected with RCAS-PBIG and primary brain cell cultures infected with the same vector were seeded and grown on sterilized glass coverslips. First, the cells were fixed by immersing the coverslips in $2 \mathrm{~mL}$ of $4 \%$ paraformaldehyde in PBS (pH 7.4) for $30 \mathrm{~min}$ at room temperature. After washing with PBS three times, the coverslips were mounted on slides using Fluoromount G (EMS) and visualized under fluorescence microscope (Nikon Eclipse) using conventional FITC filter sets (Nikon B-1E, EX470-490, DM505, BA520-560) for green fluorescence. The red fluorescence of brain sections stained with antiGFP antibody (Santa Cruz Biotech) was visualized by using Texas Red filter set (Nikon G-1B, EX540/10, DM580, BA590).

\section{Giemsa staining of cultured cells}

The medium was aspirated from cells at $80 \%$ confluence and the cells were washed with PBS ( $\mathrm{pH} 7.4)$, followed by fixing in methanol at room temperature for $10 \mathrm{~min}$. Then, $1 \mathrm{~mL}$ of Giemsa stain (LabChem Inc) was applied for $5 \mathrm{~min}$. The stain was discarded and the cells were washed with PBS several times and visualized under a bright field microscope.

\section{Immunocytochemistry}

The cells infected with RCAS-PBIG or RCAS-lacZ were fixed in either $4 \%$ paraformaldehyde in $\mathrm{PBS}(\mathrm{pH} 7.4)$ or cold methanol. The dishes were blocked by using $5 \%$ normal horse serum diluted in PBS ( $\mathrm{pH}$ 7.4) for $1 \mathrm{~h}$ at room temperature with shaking. Monoclonal anti-A2B5 antibody (Chemicon), polyclonal anti-NG2 antibody (Chemicon), monoclonal anti-O4 antibody (Chemicon), monoclonal anti-GFAP antibody (Boehringer Mannheim), monoclonal anti-NeuN antibody (Chemicon), and monoclonal anti-neurofilament antibody (Boehringer Mannheim) were used as primary antibodies. Appropriate biotinylated secondary antibodies and avidin-conjugated peroxidase were purchased from Vector Lab. The signal was visualized by using DAB substrate kit (Vector Lab) and examined under microscopy.

\section{Blocking of PDGF signaling}

The cells infected with RCAS-PBIG were cultured in DMEM supplemented with $10 \%$ FCS. Cells $\left(1 \times 10^{5}\right)$ were plated and the experiment groups were treated with PTK787 (stock solution dissolved in DMSO) with the final concentration of $1 \mu \mathrm{M}$ for $2 \mathrm{wk}$. The control groups were treated with the same volume of DMSO. After two wk, the cell numbers were counted, and the morphology was visualized by Giemsa staining.

\section{Western analysis}

Whole-cell protein extracts were prepared by using cold lysis buffer consisting of: $100 \mathrm{mM} \mathrm{NaCl}, 30 \mathrm{mM}$ Tris- $\mathrm{HCl}$ (pH 7.6), $1 \%$ NP-40, $30 \mathrm{mM}$ sodium fluoride, $1 \mathrm{mM}$ EDTA, $1 \mathrm{mM}$ sodium vanadate, $0.5 \mathrm{mM}$ PMSF, and protease inhibitor cocktail tablets (Boerhinger Mannheim). Samples were incubated on ice for 30 min and supernatants were recovered by centrifuging at 14,000 $\mathrm{rpm}$ at $4^{\circ} \mathrm{C}$ for $20 \mathrm{~min}$. Protein concentrations were determined by BCA method (Pierce Biochemical). Proteins were separated on $10 \%$ SDS-PAGE and transferred to nitrocellulose membrane (Osmonics). Blocking reagent was 5\% non-fat dry milk in TBS (pH 7.4). Washing buffer was TBS (pH 7.4) with $0.1 \%$ Tween- 20. Polyclonal rabbit anti-PLP (Oncogene Research), polyclonal rabbit anti-PDGFR $\alpha$ and $\beta$ (Upstate Biotech), polyclonal goat antivimentin (Chemicon), polyclonal rabbit anti-Id4 (Santa Cruz Biotech), polyclonal rabbit anti-GFP (Santa Cruz Biotech), and monoclonal anti- $\alpha$-tubulin (Sigma) were used as primary antibodies. Respective HRP-conjugated secondary antibodies were purchased from Boehringer Mannheim. Signals were visualized by using ECL chemiluminescence (Amersham) and Kodak XOMAT films.

\section{Infection of $t v$-a-transgenic mice}

DF-1 cells producing various RCAS virons were trypsinized and pelleted by centrifugation; the pellets were resuspended in $\sim 50$ $\mu \mathrm{L}$ of DMEM medium and placed on ice before injection. Using a $10 \mu \mathrm{L}$ gas-tight Hamilton syringe, a single intracranial injection of $1 \mu \mathrm{L}$ of cell suspension $\left(\sim 10^{4}\right.$ cells) was made in the right frontal region of newborn mice, with the tip of the needle just touching the skull base.

\section{Brain sectioning, $H \& E$ staining, and immunohistochemistry}

Mice were sacrificed before (because of early symptoms) or at 12 wk of age and the whole brains were fixed in $4 \%$ formaldehyde in PBS for at least $36 \mathrm{~h}$ with shaking. Five sections of each brain were cut and embedded in paraffin, 5-micron sections were cut with a Leica microtome. The sections were stained with H\&E. Immunostaining was performed using $\mathrm{ABC}$ kits (Vector Lab). Briefly, deparaffinized slides were first treated with antigen unmasking reagent (Vector Lab) with heating in a steamer for 30 min, followed by immersing in $10 \%$ hydrogen peroxide in methanol for 20 min to inactivate the endogenous peroxidases. Then the sections were blocked with $1.5 \%$ normal horse serum in PBS (pH 7.4) for $1 \mathrm{~h}$ at room temperature. Monoclonal antiGFAP (Boehringer Mannheim), monoclonal anti-NeuN (Chemicon), polyclonal rabbit anti-synaptophysin (Biomeda), and poly- 
clonal rabbit anti-GFP (Santa Cruz Biotech) were diluted in ChemMate antibody dilution buffer (Ventana Medical Systems) and incubated with sections at $37^{\circ} \mathrm{C}$ for $1 \mathrm{~h}$. After washing with PBS/0.05\% Tween 20, appropriate biotinylated secondary antibodies (Vector Lab) diluted in the same antibody dilution buffer were incubated with sections at $37^{\circ} \mathrm{C}$ for $30 \mathrm{~min}$. Then, after washing, avidin-conjugated peroxidase or alkaline phosphatase (Vector Lab) diluted in PBS containing 1.5\% normal horse serum was incubated with sections for $30 \mathrm{~min}$ at room temperature. Finally, after exclusive PBS-T washing, DAB or alkaline phosphatase red substrate (Vector Lab) was added to develop the color. After terminating the staining reaction, the sections were counterstained with hematoxylin and mounted. The negative controls were included with the same procedure except replacing primary antibodies with antibody dilution buffer.

\section{FISH}

The following BACs (Research Genetics, Huntsville, AL) were used to assay for chromosomal loss at murine regions syntenic to human glioma tumor suppressor regions (human/mouse homology maps are available at http://www.ncbi.nlm.nih.gov/ Homology/index.html and http://greengenes.llnl.gov/mouse/): for regions syntenic to human $1 \mathrm{p}, \mathrm{BAC} 432-\mathrm{H}-2$ (murine chromosome 3, $84.9 \mathrm{cM}$ ) (Korenberg et al. 1999), BAC 150-L-24 (murine chromosome 4, $46.6 \mathrm{cM}$ ) (Chua et al. 1996), and BAC 362D-3 (murine chromosome 4, $81.5 \mathrm{cM}$ ) (Korenberg er al. 1999); for regions syntenic to human $19 \mathrm{q} 13.3$, BACs $305-\mathrm{J}-2$ (murine chromosome 7, 4-5.5 cM) and 419-I-21 (murine chromosome 7, 23.0 $\mathrm{cM}$ ); for the Pten locus, BAC 371-O-8 (murine chromosome 19, $26 \mathrm{cM}$ ) (Hansen and Justice 1999). Centromeric BACs were also used to confirm copy numbers for chromosomes 3, 4, 7, and 19 (BAC 52-H-9, chromosome 3; BAC 39-B-18, chromosome 4; BAC 43-A-19, chromosome 7; and BAC 26-B-5, chromosome 19) (Korenberg et al. 1999). Purified BAC DNA was fluorescently labeled with SpectrumOrange or SpectrumGreen (Vysis Inc., Downers Grove, IL) by nick translation and applied to slidemounted tissue sections that had been dewaxed, rehydrated, and treated in $10 \mathrm{mM}$ sodium citrate for $30 \mathrm{~min}$ at $80^{\circ} \mathrm{C}$ and pepsin $(4 \mathrm{mg} / \mathrm{mL}$ in saline, $\mathrm{pH}$ is adjusted to 1.5 with $\mathrm{HCl}$ ) for 15 min. Following denaturation for $10 \mathrm{~min}$ at $80^{\circ} \mathrm{C}$, the sections were incubated overnight at $37^{\circ} \mathrm{C}$. After washing in buffers at $45^{\circ} \mathrm{C}(2 \times 15 \mathrm{~min}$ in $1.5 \mathrm{M}$ urea $/ 0.1 \times \mathrm{SSC}, 5 \mathrm{~min}$ in $2 \times \mathrm{SSC}, 5 \mathrm{~min}$ in $2 \times \mathrm{SSC} / 0.1 \% \mathrm{NP}-40)$, the slides were counterstained with 4,6-diaminidino-2-pheny-indol (DAPI), covered with coverslips and evaluated by fluorescence microscopy. Nuclear signals were counted from a total of 100 cells in areas of solid tumor. Cells were considered to have two copies of the chromosome when the signal average was between 1.7 and 2.3. The region was judged to be hemizygously deleted when the signal average ranged from $0.7-1.3$, and homozygously deleted when the average was below 0.3 .

\section{Acknowledgments}

We thank Yi Li (Memorial Sloan Kettering Cancer Center) for the RCAS-LacZ vector and Dr. Timothy S. Schaefer (MD Anderson Cancer Center, Houston, TX) for the pSM-1 clone. Mice with targeted deletions of Ink4a-Arf were obtained from Ron DePinho (Dana Farber Cancer Center) and those with targeted deletions for p53 were obtained from Larry Donehower (Baylor University). The PDGF receptor kinase inhibitor PTK787/ZK222584 was a gift of Jeanette Wood (Novartis). This work was supported by NIH grant UO1CA894314-1 and the Searles Scholars Program.
The publication costs of this article were defrayed in part by payment of page charges. This article must therefore be hereby marked "advertisement" in accordance with 18 USC section 1734 solely to indicate this fact.

\section{References}

Andres-Barquin, P.J., Hernandez, M.C., and Israel, M.A. 1999. Id4 expression induces apoptosis in astrocytic cultures and is down-regulated by activation of the cAMP-dependent signal. Exp. Cell Res. 247: 347-355.

Asakura, K., Suzumura, A., Rodriguez, M., and Sawada, M. 1998. Differentiation-specific mRNA expression of a mouse bipotential glial cell line. Neurosci. Lett. 258: 21-24.

Bello, M.J., Leone, P.E., Vaquero, J., de Campos, J.M., Kusak, M.E., Sarasa, J.L., Pestana, A., and Rey, J.A. 1995. Allelic loss at $1 \mathrm{p}$ and $19 \mathrm{q}$ frequently occurs in association and may represent early oncogenic events in oligodendroglial tumors. Int. J. Cancer 64: 207-210.

Bertrand, P., Rouillard, D., Boulet, A., Levalois, C., Soussi, T., and Lopez, B.S. 1997. Increase of spontaneous intrachromosomal homologous recombination in mammalian cells expressing a mutant P53 protein. Oncogene 14: 1117-1122.

Bigner, S.H., Mattmews, M.R., Rasheed, B.K., Wiltshire, R.N., Friedman, H.S., Friedman, A.H., Stenzel, T.T., Dawes, D.M., McLendon, R.E., and Bigner, D.D. 1999. Molecular genetic aspects of oligodendrogliomas including analysis by comparative genomic hybridization. Am. I. Pathol. 155: 375386.

Cairncross, J.G., Ueki, K., Zlatescu, M.C., Lisle, D.K., Finkelstein, D.M., Hammond, R.R., Silver, J.S., Stark, P.C., Macdonald, D.R., Ino, Y., et al. 1998 Specific chromosomal losses predict chemotherapeutic response and survival in patients with anaplastic oligodendrogliomas. I. Natl. Cancer Inst. 90: $1473-1479$.

Chau, S.C., Chung, W.K., Wu-Peng, X.S., Zhang, Y., Liu, S.M., Tartaglia, L., and Leibel, R.L. 1996. Phenotypes of mouse diabetes and rat fatty due to mutations in the $\mathrm{OB}($ leptin) receptor. Science 271: 994-996.

Claesson-Welsh, L., Eriksson, A., Westermark, B., and Heldin, C.H. 1989. cDNA cloning and expression of the human Atype platelet-derived growth factor (PDGF) receptor establishes structural similarity to the B-type PDGF receptor. Proc. Natl. Acad. Sci. 86: 4917-4921.

De Vries-Smits, A.M., Burgering, B.M., Leevers, S.J. Marshall, C.J., and Bos, J.L. 1992. Involvement of p21 ras in activation of extracellular signal-regulated kinase2. Nature 357:602604.

Di Rocco, F., Carroll, R.S., Zhang, J., and Black, P.M. 1998. Platelet-derived growth factor and its receptor expression in human oligodendrogliomas. Neurosurgery 42: 341-346.

Donehower, L.A., Godley, L.A., Aldaz, C.M., Pyle, R., Shi, Y.P., Pinkel, D., Gray, J., Bradley, A., Medina, D., and Varmus, H.E. 1995. Deficiency of p53 accelerates mammary tumorigenesis in Wnt-1 transgenic mice and promotes chromosomal instability. Genes \& Dev. 9: 882-895.

Dubois-Dalcq, M. 1987. Characterization of a slowly proliferative cell along the oligodendrocyte differentiation pathway. EMBO I. 6: 2587-2595.

Franke, T.F., Yang, S.I., Chan, T.O., Datta, K., Kazalauskas, A., Morrison, D.K., Kaplan, D.R., and Tsichlis, P.N. 1995. The protein kinase encoded by the Akt proto-oncogene is a target of the PDGF-activated phosphatidylinositol 3-kinase. Cell 81: 727-736.

Fruttiger, M., Calver, A.R., Kruger, W.H., Mudhar, H.S., Micha- 
lovich, D., Takakura, N., Nishikawa, S., and Richardson, W.D. 1996. PDGF mediates a neuron-astrocyte interaction in the developing retina. Neuron 17: 1117-1131.

Guha, A., Dashner, K., Black, P.M., Wagner, J.A., and Stiles, C.D. 1995. Expression of PDGF and PDGF receptors in human astrocytoma operation specimens supports the existence of an autocrine loop. Int. J. Cancer 60: 168-173.

Hall, A., Giese, M.A., and Richardson, W.D. 1996. Spinal cord oligodendrocytes develop from ventrally derived progenitor cells that express PDGF $\alpha$-receptors. Development 122: 4085-4094.

Hansen, G.M. and Justice, M.J. 1999. Activation of Hex and $m E g 5$ by retroviral insertion may contribute to mouse B-cell leukemia. Oncogene. 18: 6531-6539.

Hart, I.K., Richardson, W.D., Heldin, C.H., Westermark, B., and Raff, M.C. 1989. PDGF receptors on cells of the oligodendrocyte-type-2 astrocyte (O-2A) cell lineage. Development 105: 595-603.

Hermanson, M., Funa, K., Hartman, M., Claesson-Welsh, L., Heldin, C.-H., Westermark, B., and Nister, M. 1992. Plateletderived growth factor and its receptors in human glioma tissue: Expression of messenger RNA and protein suggests the presence of autocrine and paracrine loops. Cancer Res. 52: 3213-3219.

Hermanson, M., Funa, K., Westermark, B., Heldin, C.-H., Wiestler, O.D., Louis, D.N., von Deimling, A., and Nister, M. 1996. Association of loss of heterozygosity on chromosome $17 \mathrm{p}$ with high platelet-derived growth factor a receptor expression in human malignant gliomas. Cancer Res. 56: 164 171.

Holland, E.C. 2001. Gliomagenesis: Genetic alterations and mouse models. Nat. Rev. Genet. 2: 120-129.

Holland, E.C. and Varmus, H.E. 1998. Basic fibroblast growth factor induces cell migration and proliferation after glia-specific gene transfer in mice. Proc. Natl. Acad. Sci. 95: 12181223.

Holland, E.C., Hively, W.P., DePinho, R.A., and Varmus, H.E. 1998a. A constitutively active epidermal growth factor receptor cooperates with disruption of G1 cell-cycle arrest pathways to induce glioma-like lesions in mice. Genes \& Dev. 12: 3675-3685.

Holland, E.C., Hively, W.P., Gallo, V., and Varmus, H.E. 1998 b. Modeling mutations in the $\mathrm{G}_{1}$ arrest pathway in human gliomas: Overexpression of CDK4 but not loss of Ink4a-Arf induces hyperploidy in cultured mouse astrocytes. Genes \& Dev. 12: 3644-3649.

Holland, E.C., Celestino, J., Dai, C., Schaefer, L., Sawaya, R.E., and Fuller, G.N. 2000a. Combined activation of Ras and Akt in neural progenitors induces glioblastoma formation in mice. Nat. Genet. 25: 55-57.

Holland, E.C., Li, Y., Celestino, J., Dai, C., Schaefer, L., Sawaya, R.A., and Fuller, G.N. 2000b. Astrocytes give rise to oligodendrogliomas and astrocytomas after gene transfer of polyoma virus middle $\mathrm{T}$ antigen in vivo. Am. I. Pathol. 157: 1031-1037.

Hutchins, J.B. 1995. Platelet-derived growth factor receptors of mouse central nervous system cells in vitro. J. Comp. Neurol. 360: 59-80.

Ichimura, K., Schmidt, E.E., Goike, H.M., and Collins, V.P. 1996. Human glioblastomas with no alterations of the CDKN2 (p16INK4A, MTS1) and CDK4 genes have frequent mutations of the retinoblastoma gene. Oncogene 13: 10651072.

Ino, Y., Betensky, R.A., Zlatescu, M.C., Sasaki, H., Macdonald, D.R., Stemmer-Rachamimov, A.O., Ramsay, D.A., Cairncross, J.G., and Louis, D.N. 2001. Molecular subtypes of ana- plastic oligodendroglioma: Implications for patient management at diagnosis. Clin. Cancer Res. 7: 839-845.

Kondo, T. and Raff, M. 2000. The Id4 HLH protein and the timing of oligodendrocyte differentiation. EMBO $\mathrm{J}$. 19: $1998-2007$.

Korenberg, J.R., Chen, X., Devon, K.L., Noya, D., Oster-Granite, M.L., and Birren, B.W. 1999. Mouse molecular cytogenetic resource: 157 BACs link the chromosomal and genetic maps. Genome Res. 9: 514-523.

Louis, D.N. and Cavanee, W.K. 1997. Neoplasms of the central nervous system: Molecular biology of central nervous system neoplasms. In Cancer: Principles and practice of oncology, Ed. 5. (ed. V. DeVita, S. Hellman, and S. Rosenberg), pp. 2013-2022. Lippincott-Raven, Philidelphia, PA.

Louis, D.N., von Deimling, A., Chung, R.Y., Rubio, M.P., Whaley, J.M., Eibl, R.H., Ohgaki, H., Wiestler, O.D., Thor, A.D., and Seizinger, B.R. 1993. Comparative study of p53 gene and protein alterations in human astrocytic tumors. J. Neuropathol. Exp. Neurol. 52: 31-38.

Maier, D., Comparone, D., Taylor, E., Zhang, Z., Gratzl, O., Van Meir, E.G., Scott, R.J., and Merlo, A. 1997. New deletion in low-grade oligodendroglioma at the glioblastoma suppressor locus on chromosome 10q25-26. Oncogene 15: 997-1000.

Moriya, S., Kazlauskas, A., Akimoto, K., Hirai, S., Mizuno, K., Takenawa, T., Fukui, Y., Watanabe, Y., Ozaki, S., and Ohno, S. 1996. Platelet-derived growth factor activates protein kinase $\mathrm{C} \epsilon$ through redundant and independent signaling pathways involving phospholipase $\mathrm{C} \gamma$ or phosphatidylinositol 3-kinase. Proc. Nat1. Acad. Sci. 93: 151-155.

Nister, M., Libermann, T.A., Betsholtz, C., Pettersson, M., Claesson-Welsh, L., Heldin, C.H., Schlessinger, J., and Westermark, B. 1988. Expression of messenger RNAs for platelet-derived growth factor and transforming growth factor-a and their receptors in human malignant glioma cell lines. Cancer Res. 48: 3910-3918.

Noble, M., Murray, K., Stroobant, P., Waterfield, M.D., and Riddle, P. 1988 Platelet-derived growth factor promotes division and motility and inhibits premature differentiation of the oligodendrocyte/type-2 astrocyte progenitor cell. Nature 333: $560-562$.

Nogueira, M.M., Mitjavila-Garcia, M.T., Le Pesteur, F., Filippi, M.D., Vainchenber, W., Dubart Kupperschmitt, A., and Sainteny, F. 2000. Regulation of Id gene expression during embryonic stem cell-derived hematopoietic differentiation. Biochem. Biophys. Res. Commun. 276: 803-812.

Ohgaki, H., Eibl, R.H., Schwab, M., Reichel, M.B., Mariami, L., Gehring, M., Petersen, I., Holl, T., Wiestler, O.D., and Kleihues, P. 1993. Mutations of the p53 tumor suppressor gene in neoplasms of the human nervous system. Mol. Carcinog. 8: 74-80.

Raff, M.C., Miller, R.H., and Noble, M. 1983 A glial progenitor cell that develops in vitro into an astrocyte or an oligodendrocyte depending on culture medium. Nature 303: 390396.

Ransom, D.T., Ritland, S.R., Kimmel, P.J., Moertel, C.A., Dahl, R.J., Scheithauer, R.B., Kelly, P.J., and Jenkins, R.B. 1992. Cytogenetic and loss of heterozygosity studies in ependymomas, pilocytic astrocytomas, and oligodendrogliomas. Genes Chromomosomes Cancer 5: 348-356.

Reifenberger, J., Reifenberger, G., Liu, L., James, C.D., Wechsler, W., and Collins, V.P. 1994. Molecular genetic analysis of oligodendroglial tumors shows preferential allelic deletions on 19q and 1p. Am. J. Pathol. 145: 1175-1190.

Richardson, W.D., Pringle, N., Mosley, M.J., Westermark, B., and Dubois-Dalcq, M. 1988. A role for platelet-derived growth factor in normal gliogenesis in the central nervous 
system. Cell 53: 309-319.

Robinson, S., Cohen, M., Prayson, R., Ransohoff, R.M., Tabrizi, N., and Miller, R.L.H. 2001. Constitutive expression of growth-related oncogenes and its receptor in oligodendrogliomas. Neurosurgery 48: 864-873.

Sara, V.R., Prisell, P., Sjogren, B., Persson, L., Boethius, J., and Enberg, G. 1986. Enhancement of insulin-like growth factor 2 receptors in glioblastoma. Cancer Lett. 32: 229-234.

Scherer, H.J. 1938. Structural development in gliomas. Am. I. Cancer 34: 333-351.

Shoshan, Y., Nishiyama, A., Chang, A., Mork, S., Barnett, G.H., Cowell, J.K., Trapp, B.D., and Staugaitis, S.M. 1999 Expression of oligodendrocyte progenitor cell antigens by gliomas: Implications for the histogenesis of brain tumors. Proc. Natl. Acad. Sci. 96: 10361-10366.

Smith, J.S., Wang, X.Y., Qian, J., Hosek, S.M., Scheithauer, B.W., Jenkins, R.B., and James, C.D. 2000. Amplification of the platelet-derived growth factor receptor-A (PDGFRA) gene occurs in oligodendrogliomas with grade IV anaplastic features. J. Neuropathol. Exp. Neurol. 59: 495-503.

Sommer, I. and Schachner, M. 1981. Monoclonal antibodies (O1 to O4) to oligodendrocyte cell surfaces: An immunocytological study in the central nervous system. Dev. Biol. 83: $311-$ 327.

Spassky, N., Goujet-Zalc, C., Parmantier, E., Oliver, C., Martinez, S., Ivanova, A., Ikenaka, K., Macklin, W., Cerruti, I., Zalc, B., et al. 1998. Multiple restricted origin of oligodendrocytes. J. Neurosci. 18: 8331-8343.

Stallcup, W.B. and Beasley, L. 1987. Bipotential glial precursor cells of the optic nerve express the NG2 proteoglycan. I. Neurosci. 7: 2737-2744.

Trojan, T., Blossey, B.K., Johnson, T.R., Rudin, S.D., Tykocinski, M., and Ilan, J. 1992. Loss of tumorigenicity of rat glioblastoma directed by episome-based antisense cDNA transcription of insulin-like growth factor I. Proc. Natl. Acad. Sci. 89: 4874-4878.

Uhrbom, L., Hesselager, G., Nister, M., and Westermark, B. 1998. Induction of brain tumors in mice using a recombinant platelet-derived growth factor B-chain retrovirus. Cancer Res. 58: 5275-5279.

von Deimling, A., Louis, D.N., von Ammon, K., Petersen, I., Wiestler, O.D., and Seizinger, B.R. 1992. Evidence for a tumor suppressor gene on chromosome 19q associated with human astrocytomas, oligodendrogliomas and mixed gliomas. Cancer Res. 52: 4277-4279.

Weber, R.G., Sabel, M., Reifenberger, J., Sommer, C., Oberstrass, J., Reifenberger, G., Kiessling, M., and Cremer, T. 1996. Characterization of genomic alterations associated with glioma progression by comparative genomic hybridization. Oncogene 13: 983-994.

Williams, B.P., Abney, E.R., and Raff, M.C. 1985. Macroglial cell development in embryonic rat brain: Studies using monoclonal antibodies, fluorescence activated cell sorting, and cell culture. Dev. Biol. 112: 126-134.

Wong, A.J., Bigner, S.H., Bigner, D.D., Kinzler, K.W., Hamilton, S.R., and Vogelstein, B. 1987. Increased expression of the epidermal growth factor receptor gene in malignant gliomas is invariably associated with gene amplification. Proc. Natl. Acad. Sci. 84: 6899-6903.

Wong, A.J., Ruppert, J.M., Bigner, S.H., Grzeschik, C.H., Humphrey, P.A., Bigner, D.S., and Vogelstein, B. 1992. Structural alterations of the epidermal growth factor receptor gene in human gliomas. Proc. Natl. Acad. Sci. 89: 2965-2969.

Wood, J., Bold, G., Buchdunger, E., Cozens, R., Ferrari, S., Frei, J., Hofmann, F., Mestan, J., Mett, H., O'Reilly, T., et al. 2000. PTK787/ZK 222584, a novel and potent inhibitor of VEGF receptor tyrosine kinases, impairs VEGF-induced responses and tumor growth after oral administration. Cancer Res. 60: $2178-2189$.

World Health Organization classification of tumours of the central nervous system. 2000. (ed. P. Kleihues and W.K. Cavenee), pp. 65-69. IARC/WHO, Lyon, France.

Wu, J.K., Ye, Z., and Darras, B.T. 1993. Frequency of p53 tumor suppressor gene mutations in human primary brain tumors. Neurosurgery 33: 824-830.

Yahanda, A.M., Bruner, J.M., Donehower, L.A., and Morrison, R.S. 1995. Astrocytes derived from p53-deficient mice provide a multistep in vitro model for development of malignant gliomas. Mol. Cell Biol. 15: 4249-4259.

Yamaguchi, F., Saya, H., Bruner, J.M., and Morrison, R. 1994. Differential expression of two fibroblast growth factor-receptor genes is associated with malignant progression in human astrocytomas. Proc. Natl. Acad. Sci. 91: 484-488. 


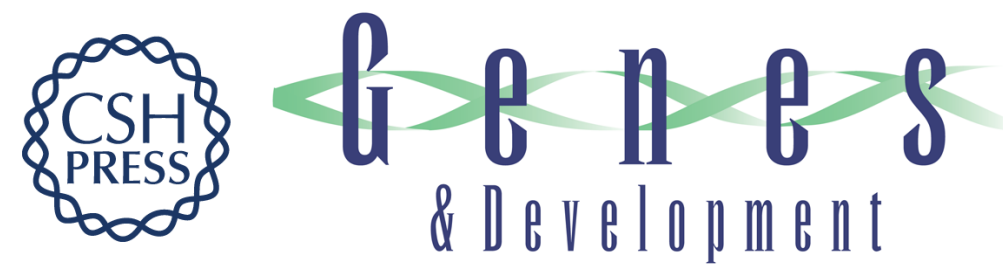

\section{PDGF autocrine stimulation dedifferentiates cultured astrocytes and induces oligodendrogliomas and oligoastrocytomas from neural progenitors and astrocytes in vivo}

Chengkai Dai, Joseph C. Celestino, Yoshifumi Okada, et al.

Genes Dev. 2001, 15:

Access the most recent version at doi:10.1101/gad.903001

References This article cites 61 articles, 27 of which can be accessed free at:

http://genesdev.cshlp.org/content/15/15/1913.full.html\#ref-list-1

License

Email Alerting

Receive free email alerts when new articles cite this article - sign up in the box at the top

Service

right corner of the article or click here.

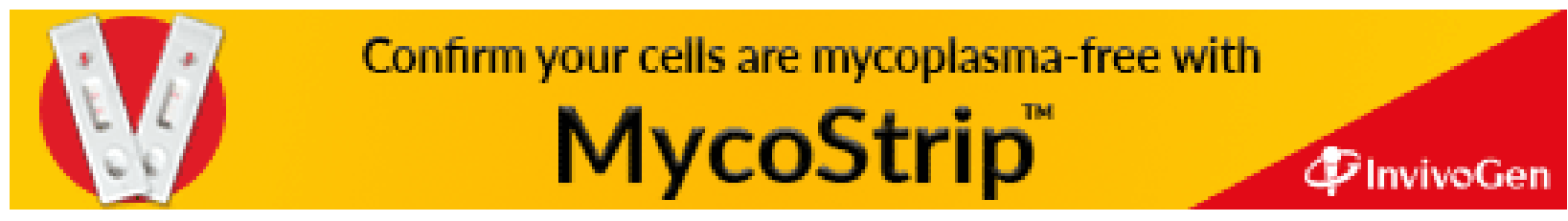

